\title{
CSAMT investigations of the Caferbeyli (Manisa/Turkey) geothermal area
}

\author{
Sinem AykaÇ ${ }^{1}$, Emre Timur ${ }^{2, *}$, Coşkun Sari ${ }^{2}$ and Çagri Çaylak ${ }^{3}$ \\ ${ }^{1}$ General Directorate of Mineral Research and Exploration, Department of Geophysics, 06520, Ankara, Turkey. \\ ${ }^{2}$ Department of Geophysical Engineering, Dokuz Eylül University, 35160, Buca, Izmir, Turkey. \\ ${ }^{3}$ Municipality of Aydrn, Aydın, Turkey. \\ *Corresponding author.e-mail: emre.timur@deu.edu.tr
}

\begin{abstract}
Western Turkey is one of the most remarkable regions of very active continental extension in the world. The most significant structures of this region are Alaşehir, Gediz, and Büyük Menderes Grabens. Geothermal activity around city of Manisa in Gediz Graben has been investigated by many researchers and many geothermal boreholes were drilled in order to produce electricity and for heating purposes. The Caferbeyli geothermal area is on the southern side of the Gediz Graben just west of Salihli, Manisa, Turkey. According to rising demand on thermal water around Salihli, geophysical studies were performed using the Controlled Source Audio Magnetotellurics (CSAMT) measurements near the area of Caferbeyli, and they were interpreted by the two-dimensional modelling. Vertical and horizontal resistivity sections were mapped, and it was determined that a low-resistivity layer exists in the SW part of the survey area. As a result of the studies in the area, the boundaries of the low-resistivity layer were mapped and a test drilling was recommended.
\end{abstract}

\section{Introduction}

In recent years, the demand for geothermal energy is increasing due to its clean, sustainable use as a renewable resource. Geothermal energy may be used in many ways, such as in hot springs and spas, geothermal power plants, fishing and farming industry, and heating individual buildings as well as the entire district.

Geothermal energy is the accumulation of heat energy as hot water within hot and dry rocks, steam or gases under pressure within the earth's crust at various depths. The change in physical properties of rock with temperature may be determined using electrical, electromagnetic, gravity, magnetic, seismic, radiometric, well-logging and down hole geophysical methods.
The Salihli geothermal system is situated within the confines of the county of Manisa about $100 \mathrm{~km}$ east of İzmir. Geothermal energy, produced at the Salihli-Kursunlu geothermal site and its surroundings, has been widely used for domestic heating, in about 3000 units, and increasing demand requires exploring new fields. For this purpose, geophysical studies may assist in quantifying the geothermal energy potential of the area by delineating subsurface fractures.

The study area is within the borders of the Salihli district of Manisa (figure 1). It is part of the Gediz Graben. The Bozdag mountains lie to the south, and the most important river found in the study area is the Gediz (Hermos) river. The aim of this study was to delineate the fracture zones in Caferbeyli using CSAMT method (figure 2).

Keywords. CSAMT; modelling; geothermal; Salihli; 2D inversion. 


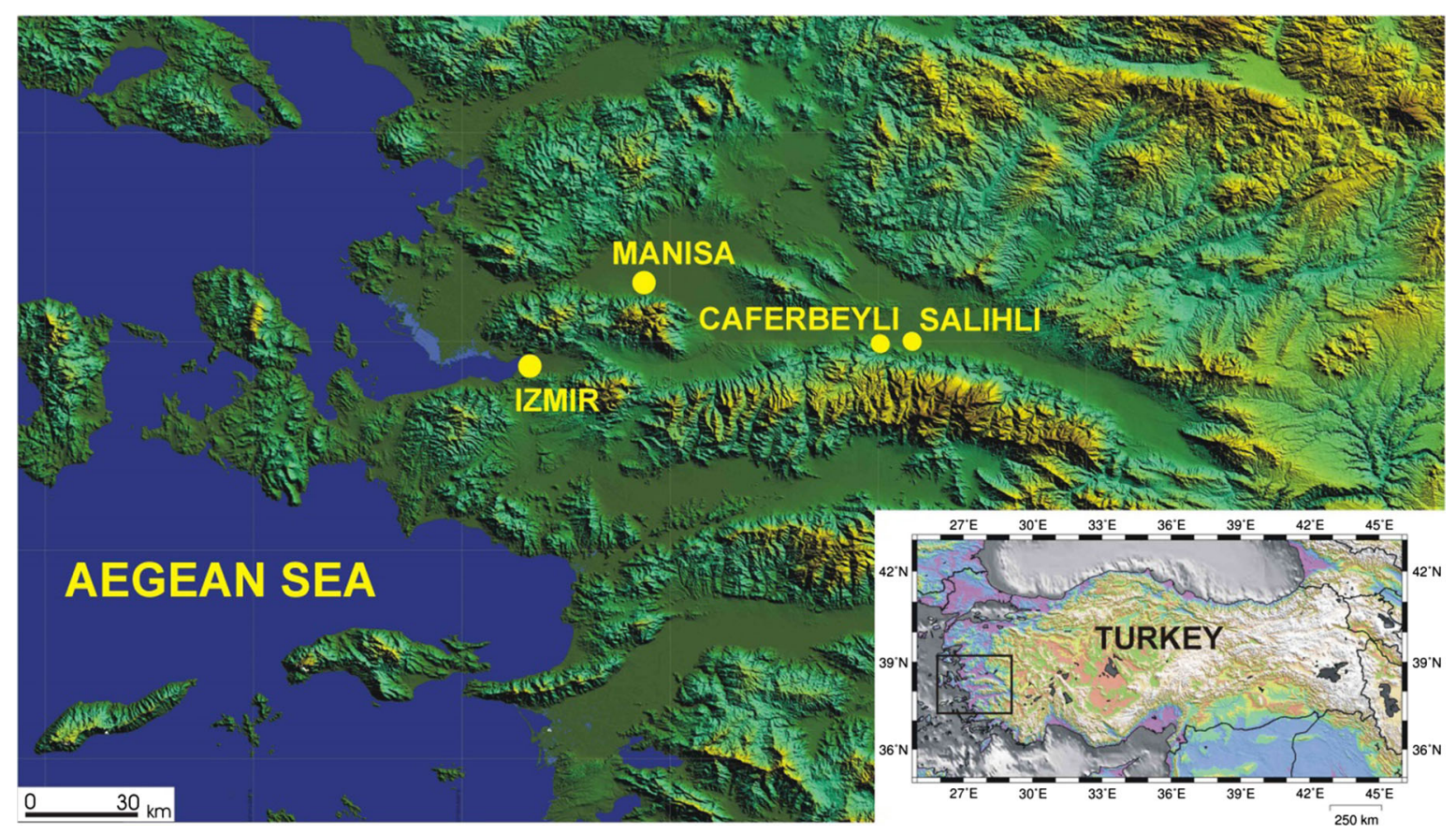

Figure 1. Location map of the study area.

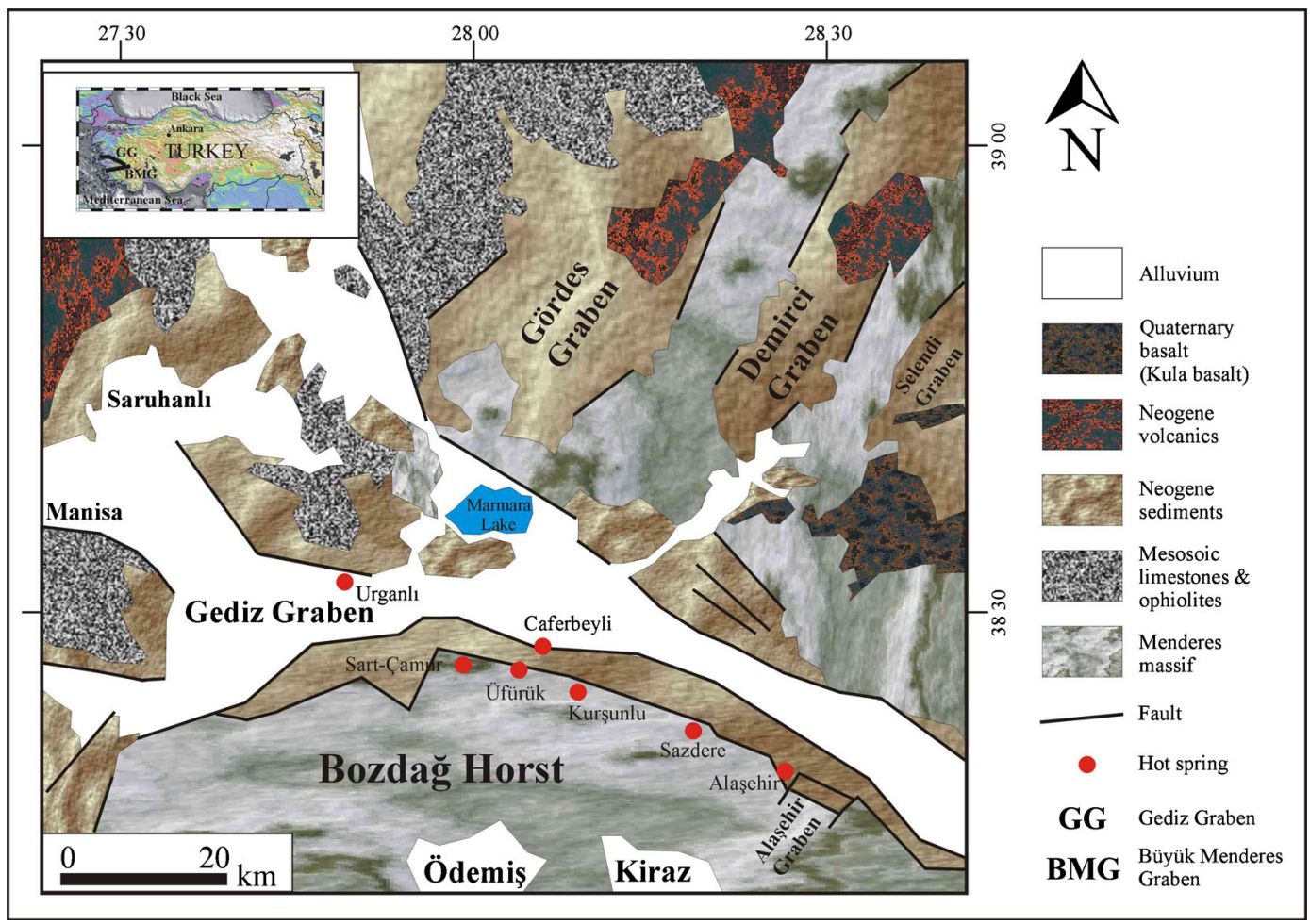

Figure 2. Geological map of the region (revised from MTA map, 1964).

The CSAMT method, one of the most applied electromagnetic methods on geothermal exploration (Ross and Moore 1985; Thanassoulas etal. 1986; Suzuki et al. 2000; Savin et al. 2001; Meju 2002; Spichak and Manzella 2009; Bujakowski et al. 2010; Sudha et al. 2011), was used in order to explore the geothermal system in the study area. The method is similar to the magnetotelluric methods with the exception that it uses an artificial source. Thus, the data acquisition system consists of two parts; transmitter unit and receiver unit. Electrical currents with various frequencies 
are injected into the ground well away from the study area by the transmitter unit. In this survey, the current electrodes are placed in a N-S direction with $2 \mathrm{~km}$ separation. Survey frequencies range between 4 and $1024 \mathrm{~Hz}$ with a binary increase. The magnetic field was measured with a magnetic coil, while the electric field was recorded using two non-polarizable electrodes placed with $200 \mathrm{~m}$ separation.

Geoelectrical model from CSAMT data has been obtained to map the geothermal features of the area.

\section{Geology and tectonics of the Gediz Graben}

Our study area is a part of western Anatolia, and the Gediz Graben is a part of a basin and range type graben system (Seyitoğlu and Scott 1996; Sözbilir 2002). The region is still seismically active and shows extension in an approximately N-S direction at a rate of $30-40 \mathrm{~mm} \mathrm{yr}^{-1}$ (McKenzie 1978; Taymaz et al. 1991; Akyol et al. 2006).

Alkaline volcanic units of western Anatolia (Aldanmaz 2002) also support the current extensional regime. In addition to volcanic eruptions between Late Miocene and Quaternary time, some magma chambers occurred in the crust. The Gediz Graben, also known as the Alasehir Graben, is one of the most well-known neotectonic structures of western Anatolia, and forms an arc-shaped structural pattern with a length of $140 \mathrm{~km}$ and a width of $10-15 \mathrm{~km}$. The topography is asymmetric, being steeper along the southern side of the graben. The southern margin of the basin has been raised along low-angle normal faults, but later the margin was elevated by high angle normal faults, which cut and displace the former. The northern margin has seismically inactive high-angle normal faults (Sözbilir 2002).

The graben is filled with Miocene to recent sedimentary deposits that have formed on the metamorphic rocks of the Menderes Massif. According to Koçyiğit et al. (1999), the graben fill comprises two contrasting in-fills that represent two distinct extensional stages: a Miocene-lower Pliocene continental sedimentary sequence (Salihli Group), which is unconformably overlain by a PlioceneQuaternary continental sequence with alkali olivine basalts (figure 3).

The inversion of the gravity data (Sarı 2003) indicated that the approximate thickness of the sedimentary layer in Gediz Graben reaches up to 2 $\mathrm{km}$. According to Purvis and Robertson (2005), the sedimentary information can be used to test two alternative tectonic models for the Gediz Graben. In the first model, an E-W graben bounded by

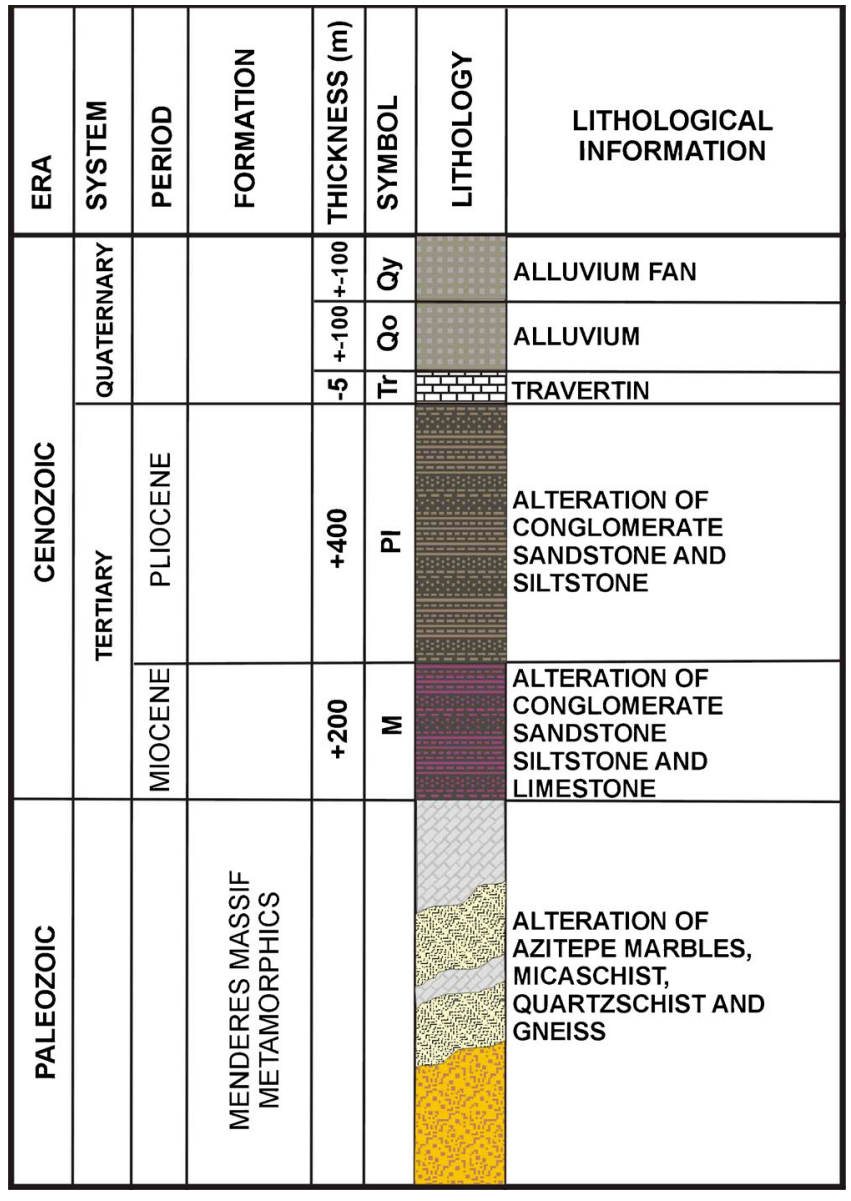

Figure 3. Stratigraphic cross-section of the study area.

high angle faults was active during latest MioceneRecent time. In the second hypothesis, the Gediz Graben was initiated much earlier, in the Early Miocene, and was then either continuously or episodically active until recent times.

\section{Hydrogeology of the Gediz Graben}

According to their locations, the thermomineral waters in the Gediz Graben geothermal areas have been physically divided into seven main groups from west to east: Urganl spa, SartÇamur spa, Caferbeyli well, Üfürük well, Kurşunlu spa, Sazdere and Alaşehir thermomineral waters (Tarcan et al. 1998). All the geothermal areas except Urganl are located along the southern rim of the graben, which is more active than the northern rim (figure 2).

The Salihli-Kursunlu geothermal field has a shallow reservoir about $200 \mathrm{~m}$ deep and contains hot springs and wells. The depth from the surface of the reservoir in this geothermal field varies between 10 and $200 \mathrm{~m}$ (Yılmazer 2003). Looking at the rock properties in the Caferbeyli region, the metamorphic Menderes gneisses contain 
water as a result of their secondary permeability. Quartzite schists are highly fractured and also include water. Mica-schist, which is one of the most common bedrock formations in the field, includes spring water, as do highly porous and permeable white marbles. On the other hand, sedimentary rocks of Miocene and Pliocene age in the area do not contain water because of the low number of fractures.

The main direction of underground water flow is from south to north. Rain water is seen as surface flow, and some of it is absorbed by the metamorphic rocks. Then, absorbed water starts to slowly follow the hydraulic slope. This constitutes the main system of water catchments in the area.

\subsection{Chemical characteristics of water}

The water of the Caferbeyli Hot Springs and surroundings includes chlorine, bi-carbonate, and low level sulphate. The amount of sodium is relatively high. The water in this region is saturated by dolomite and calcite, and as a result of this, precipitation of these minerals can be frequently observed. In spite of this, sulphate can be dissolved in this field. The partial $\mathrm{CO}_{2}$ pressure in the water is higher than the $\mathrm{CO}_{2}$ pressure in the air. Thus, gas rate in the spring water is high.

\subsection{Geothermal productivity}

The first well was drilled in 1976 to a depth of $40 \mathrm{~m}$ and the first hot water reservoir was determined at Kurşunlu, a few $\mathrm{km}$ east of Caferbeyli. Afterwards two more wells were drilled and a high volume hot water flow was achieved in 1992. As a result of this success it was planned to use these springs for heating houses. The fourth well, which is located on the north edge of the field is being used for re-injection as a result of its high porosity and permeability. The total water volume of the second and third wells was $125 \mathrm{l} / \mathrm{sec}$ which is insufficient to support 7000 houses. Therefore, it was decided to investigate the geothermal potential of Caferbeyli region and to drill an additional well, close to the locations of other boreholes.

\section{Geophysical overview of Gediz Graben}

Groups of grabens in western Anatolia are the subject of debate as to their relative ages, relationships, and geothermal potential for many researchers. All these systems were investigated using various geophysical methods such as gravity, magnetics, and magnetotelluric.

The primary objective of a gravity survey over a sedimentary basin is to delineate the shape of the basin. The most pronounced structural and morphological features of western Anatolia are caused by E-W trending normal faulting, which creates the boundaries of Büyük Menderes, Küçük Menderes, and Gediz Grabens. These grabens, which have negative Bouguer gravity anomalies are filled with Neogen sediments. These anomalies were interpreted by several researchers such as Özelçi (1973), Paton (1992), Sarı and Şalk (2002). The approximate depth to the metamorphic basement was calculated as 1.8 and $2 \mathrm{~km}$ along two almost parallel profiles by Sarı and Şalk (2002). The same depths were calculated as $1.5-2.5 \mathrm{~km}$ by

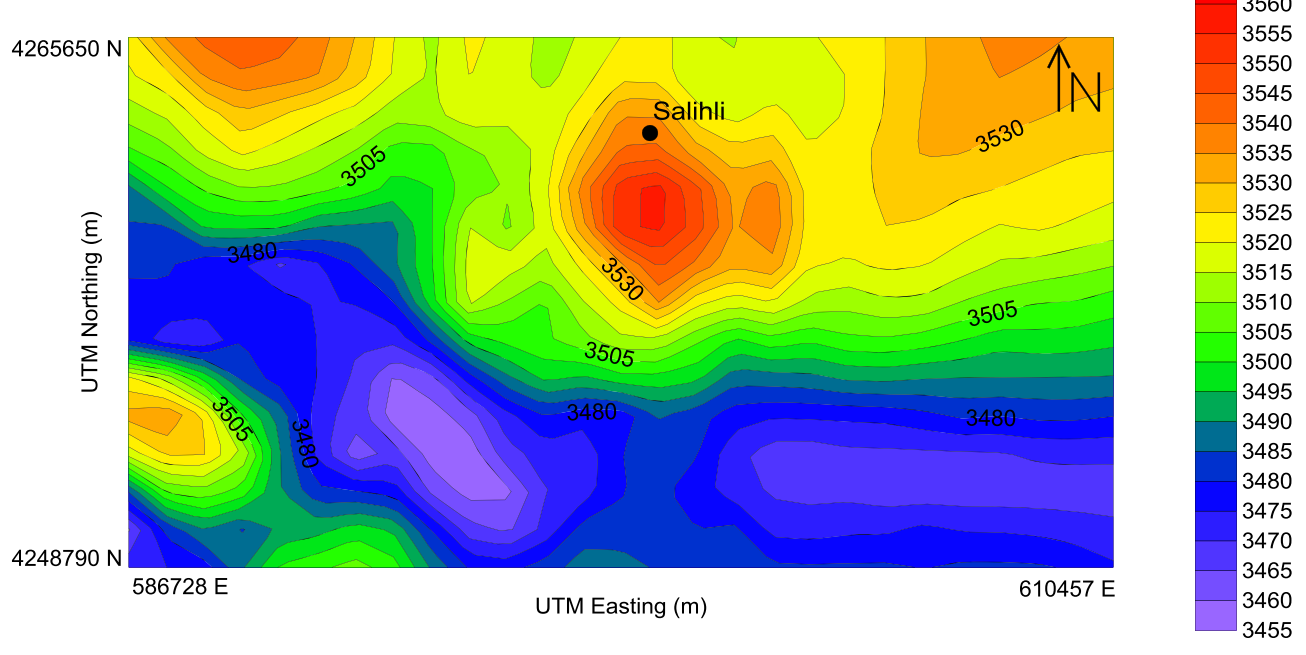

Figure 4. Regional total magnetic intensity map of the area. 
Gürer et al. (2001). According to the MT studies in Gediz Graben, it was determined that the apparent resistivity of the sedimentary fill varies between 15 and $50 \Omega \mathrm{m}$ (Gürer et al. 2001).

Also regional total magnetic field investigations were carried out at the study field by General Directorate of Mineral Research and Exploration of Turkey in 1970s. The total magnetic field data were mapped in order to determine any anomaly or sign (figure 4). Modelling methods and boundary analysing methods (Blakely 1995) are usually applied after the reduction-to-pole procedure (Baranov 1957; Baranov and Naudy 1964) (figure 5). Another method for quantitative interpretation of magnetic data is converting magnetic data into a pseudo-gravity map (Baranov 1957; Blakely and Simpson 1986) (figure 6). The black circles on the maps indicate the places where a

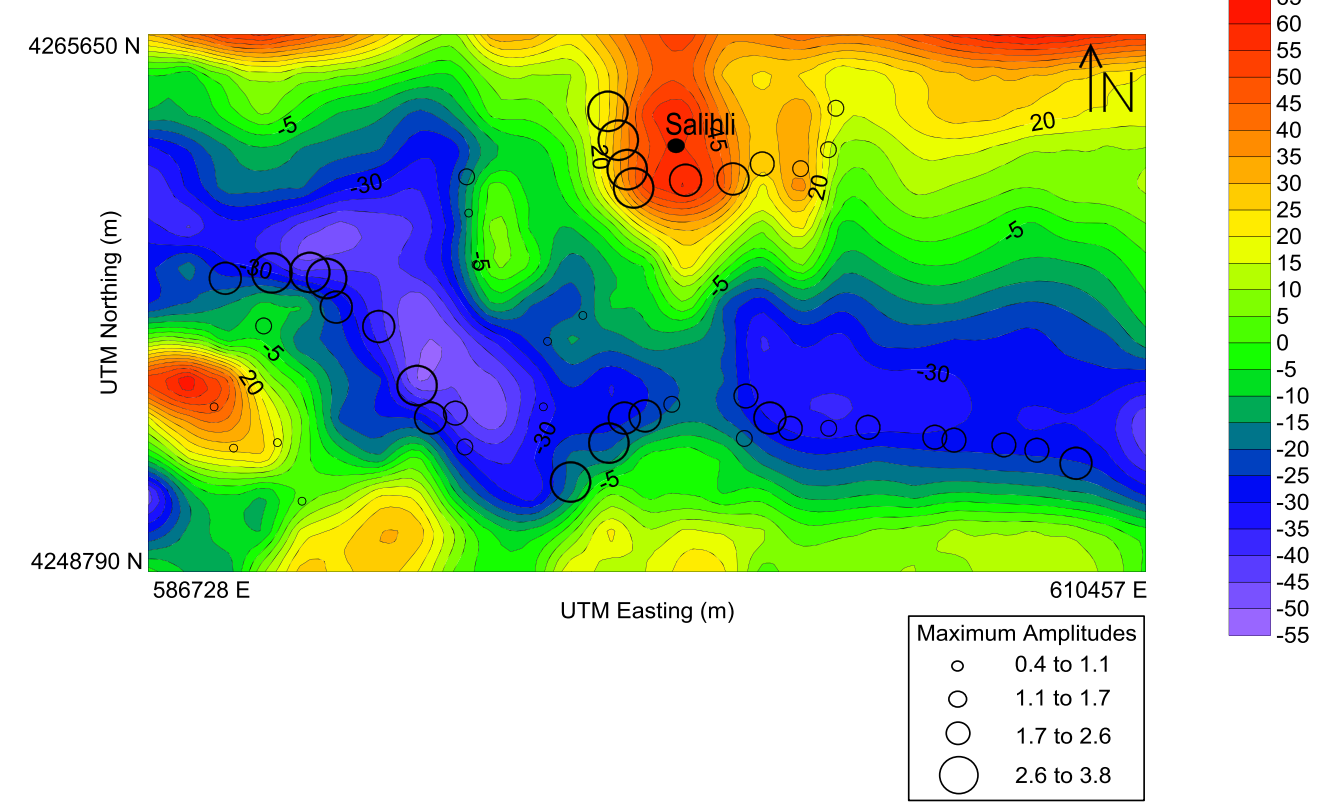

Figure 5. Reduced-to-pole map of the magnetic data and the boundary analysis.

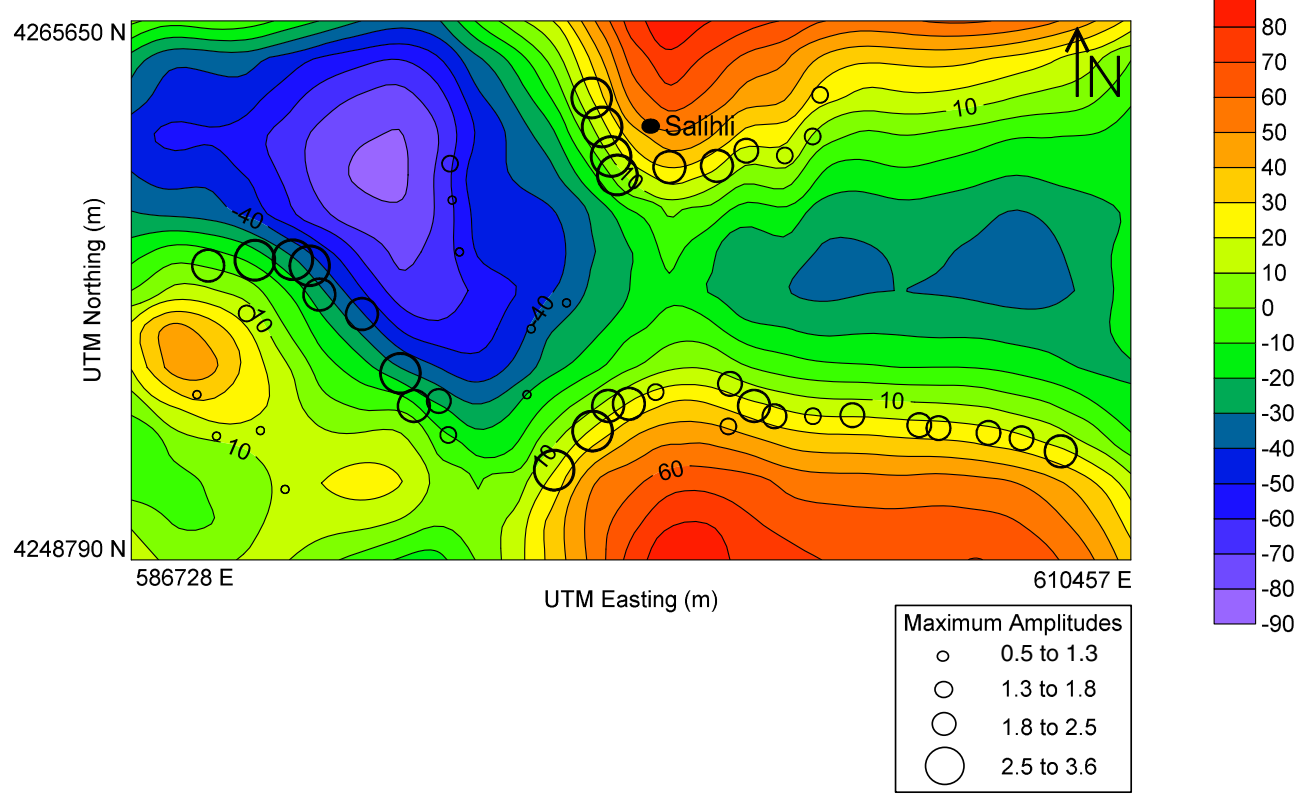

Figure 6. Pseudo-gravity map of the magnetic data and the boundary analysis. 
maximum amplitude calculated from the boundary analysis exists. The main aim of the magnetic and pseudo-gravity interpretation is to determine the possible heating rock formation.

The presence of a structure, which is termed as a mantle uplift in the south of Salihli has been determined by applying reduction to the pole and pseudo-gravity methods to the magnetic data and the boundaries of the dominant structures were found with the boundary analysis technique. Mantle uplift in the region was evaluated as a source of geothermal formation.

Also another study was utilized to determine Curie depth of the region. An average depth of $8 \mathrm{~km}$ was calculated for the area, which is very shallow for Turkey (Dolmaz et al. 2005).

\section{CSAMT applications in the study area}

In this survey a receiver, GDP-16 and a transmitter GGT-25, produced by Zonge are used. Investigations were carried out along 20 profiles in a N-S direction. The survey details of the CSAMT method, applied to the Sart-CaferbeyliÇamurhamamı region, are given in figure 7 . NS and EW are assigned $\mathrm{x}$ and $\mathrm{y}$, respectively. Each profile has 14 measurement stations and a length of $3000 \mathrm{~m}$. Seven electrical fields and one magnetic field are measured at each station along the profiles. The electrical fields $\left(E_{x}\right)$ are measured with pairs of electrodes placed along a line parallel to the source dipole and the perpendicular magnetic field $\left(H_{y}\right)$ is measured with coils. The

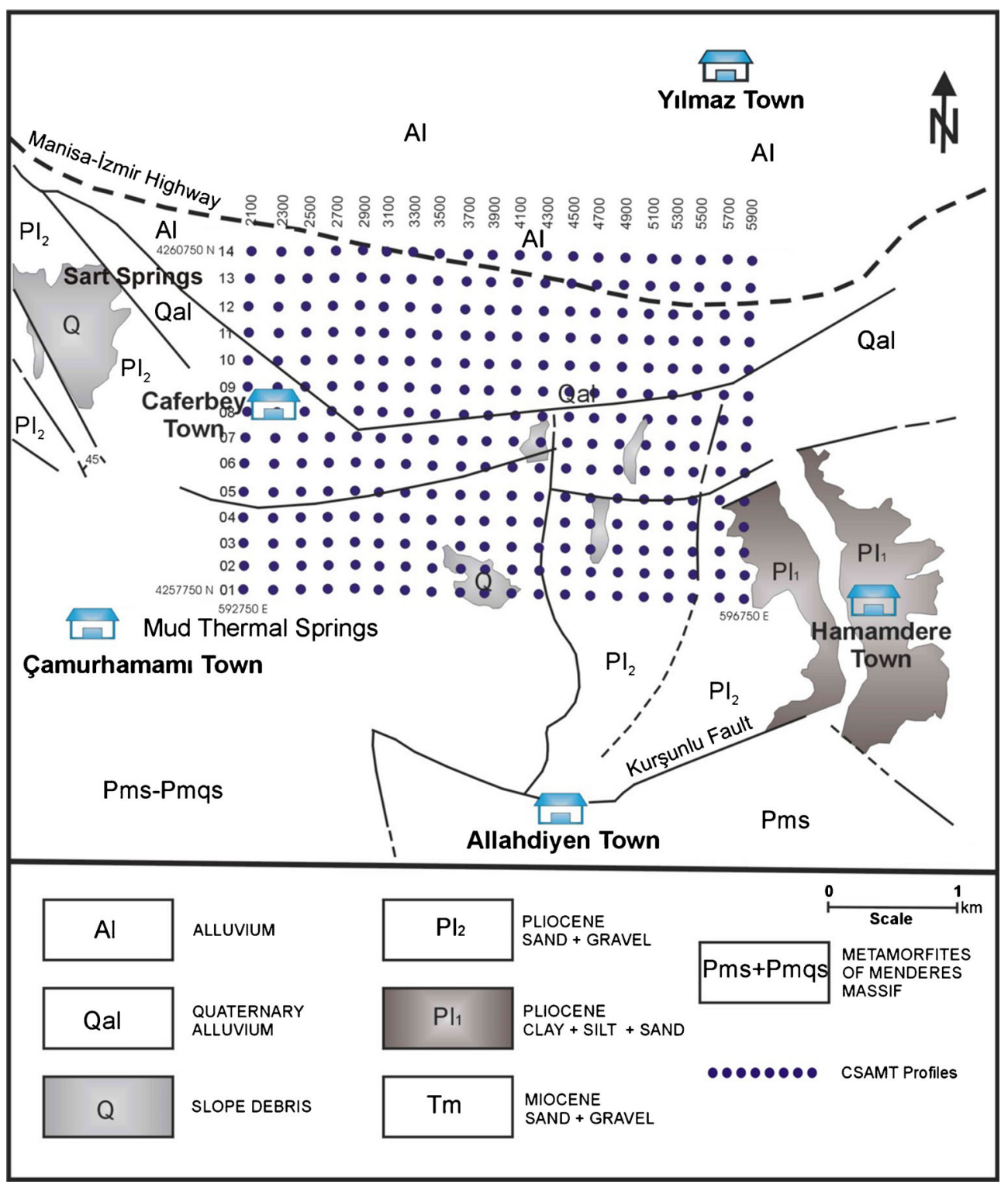

Figure 7. Location map of CSAMT profiles and geological features of the study area. 

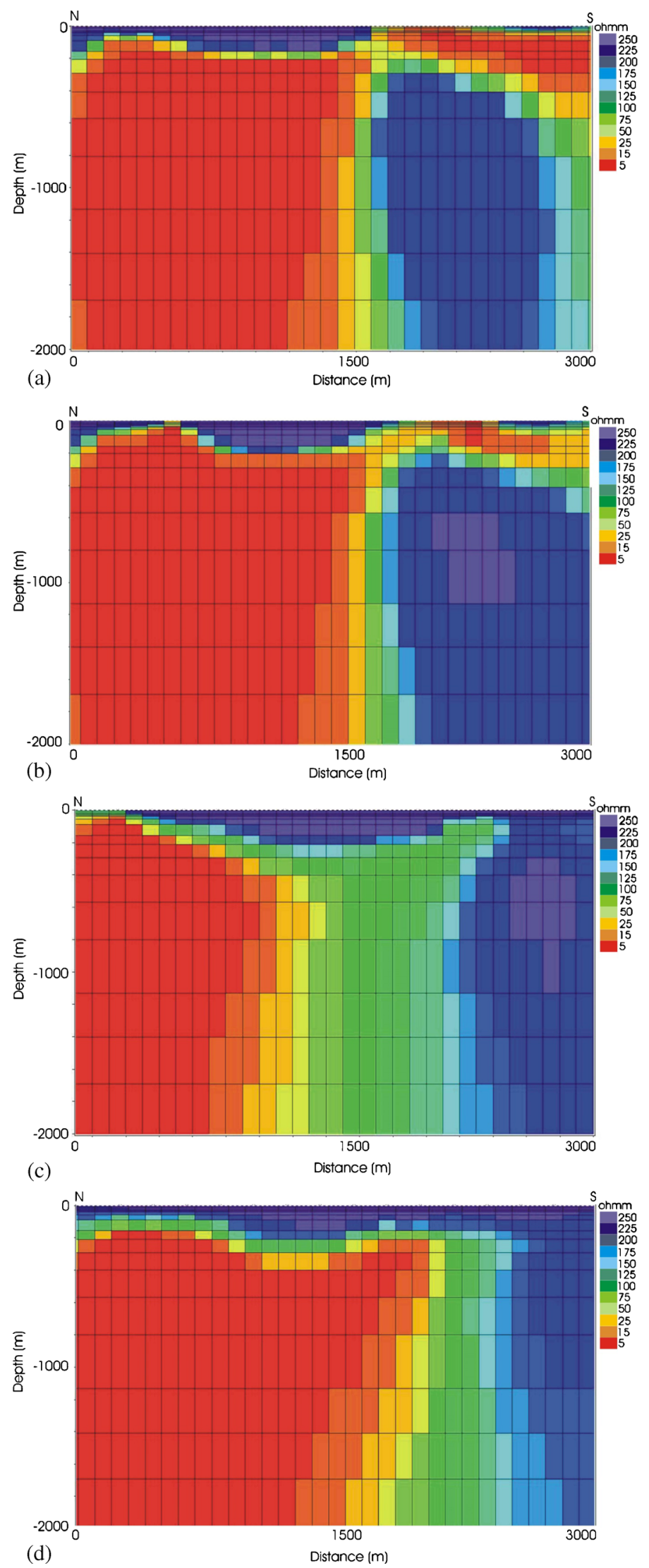

Figure 8. Vertical resistivity sections of study area (a) for line 2700 (RMS: 0.01\%), (b) for line 2900 (RMS: 0.03\%), (c) for line 3100 (RMS: $0.01 \%$ ), and (d) vertical sections of study area for line 3300 (RMS: $0.02 \%$ ). 

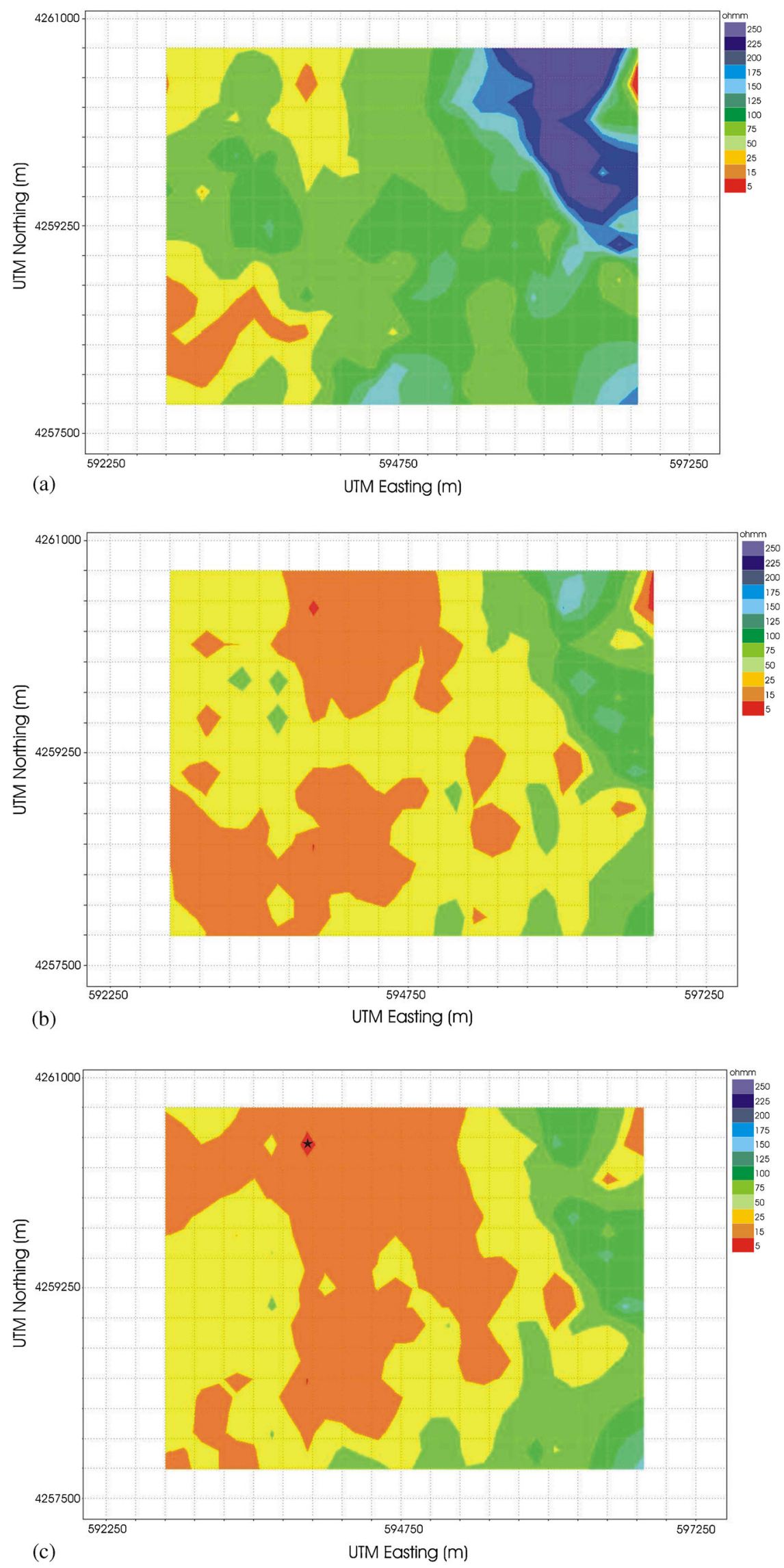

Figure 9. Horizontal resistivity cross-sections of study area (a) for $50 \mathrm{~m} \mathrm{(512} \mathrm{Hz),} \mathrm{(b)} \mathrm{for} 100 \mathrm{~m} \mathrm{(16} \mathrm{Hz)} \mathrm{and} \mathrm{(c)} \mathrm{for} 200 \mathrm{~m}$ $(4 \mathrm{~Hz})$. Black star symbol indicates the location of recommended test drilling. 
ratio of the electrical and magnetic field yields impedance:

$$
Z_{x y}=\frac{E_{x}}{H_{y}} .
$$

The apparent resistivity and phase values are calculated from impedance:

$$
\rho_{a}=\frac{1}{2 \pi \mu \cdot f}\left|Z_{x y}\right|^{2}
$$

and

$$
\phi_{a}=\tan ^{-1}\left(\frac{\operatorname{Im}\left(Z_{x y}\right)}{\operatorname{Re}\left(Z_{x y}\right)}\right) .
$$

2-D inversion techniques were applied to all CSAMT profiles to obtain reliable resistivitydepth sections. The models presented here were obtained using the WinGLink ${ }^{\mathrm{TM}}$ interpretation package consisting of a 2D inversion code of d2inv_nlcg2_fast (Mackie et al. 1993). Initial models were taken as a homogeneous half space of $50 \Omega \mathrm{m}$. Sections show that the study area was investigated down to $2000 \mathrm{~m}$ depth with the CSAMT method. Sample geoelectrical sections of the study area for line 2700, 2900, 3100, and 3300 are given in figure $8(\mathrm{a}-\mathrm{d})$. All sections indicate that there is a fault-like feature at around $1500 \mathrm{~m}$ on each profile. The structure extends beyond $2000 \mathrm{~m}$ depth. The upper $300 \mathrm{~m}$ represents the undulating base for the region. Subsidence areas have $200 \mathrm{~m}$ depth to their base and are bounded with faults.

The low-resistivity unit on the SW side of the sections is found between 250 and $2000 \mathrm{~m}$ depth in Caferbeyli region, and between 100 and $800 \mathrm{~m}$ depth in Sart Spring. Soundings indicate that this unit is quartz, a schist sequence, and mainly marble. Normally marble is expected to be a high-resistivity unit, but high temperature and hot water circulation could be responsible for low resistivity. Resistivity maps at 50, 100, and $200 \mathrm{~m}$ depth are given in figure $9(\mathrm{a}-\mathrm{c})$. Electrically conductive unit was divided into two regions as west and east parts in the study area. Highest amplitudes with the boundary analysis of magnetic and pseudo-gravity data were achieved to the west of Salihli. This transition zone can be related with the alteration of an electrically conductive unit in the east-west direction.

An apparent resistivity horizontal cross-section for $512 \mathrm{~Hz}$ is given in figure 9(a). The data are extracted from all stations and plotted according to their coordinates. The northeastern part of the area has a high resistivity unit (blue), while the southwestern part has a conductive one (red). Both represent variations in the shallow zone since the frequency is fairly high. Also two other resistivity sections are prepared for frequencies 16 and $4 \mathrm{~Hz}$. Distinctly from $512 \mathrm{~Hz}$ resistivity map, a larger low resistivity unit, between 5 and $25 \Omega \mathrm{m}$, occurred both in the north and south of the area in $16 \mathrm{~Hz}$ map (figure 9b). This low resistivity unit covered almost all of the study area in $4 \mathrm{~Hz}$ apparent resistivity map (figure 9c). The shapes of the low resistive anomalies were expanded with increasing depth and the geometry and shape of the low resistive anomaly was interpreted as the possible geometry of the thermal water saturated zone.

Based on this study, and using the stratigraphic cross-section of the region (figure 3), a geological model is proposed for Caferbeyli region (figure 10) for the profile 3100 . The surface consists of Pliocene conglomerate and sandstone units and a basin-like structure under Caferbeyli bounded with faults. The deeper structure consists of two separate units; gneiss at the northern side and marble-schist at the southern side.

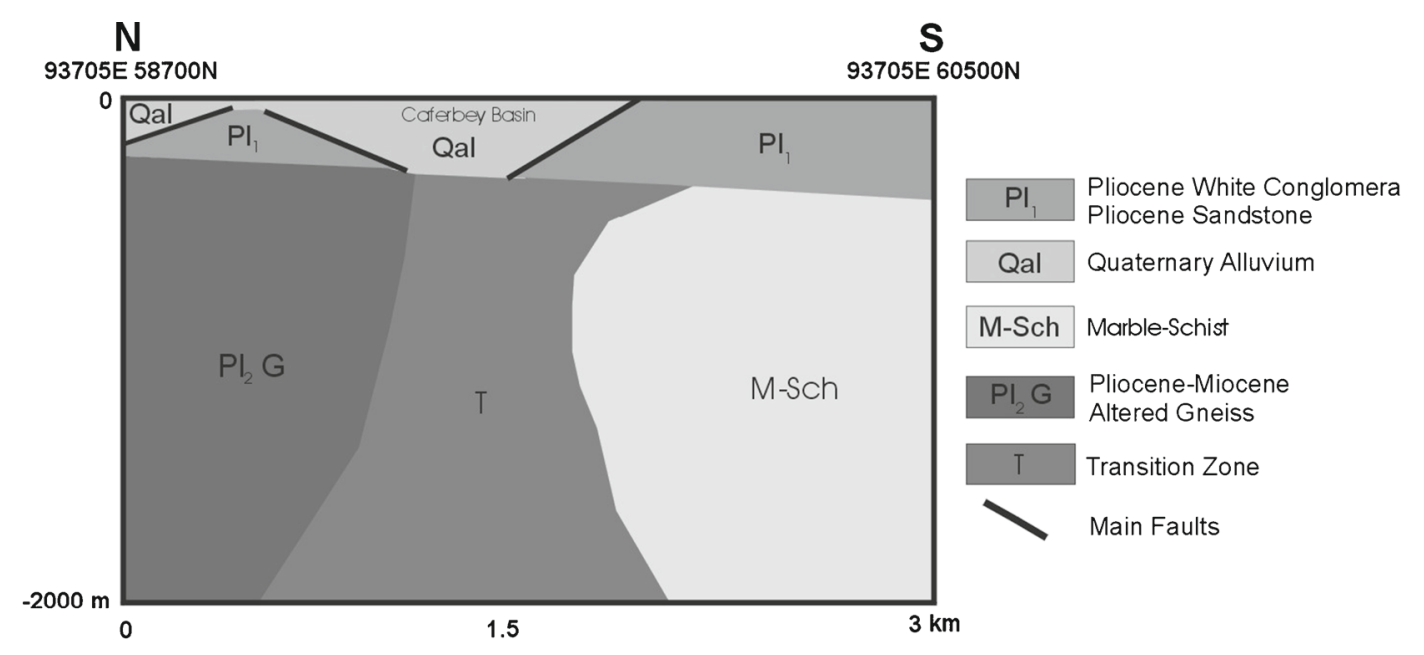

Figure 10. Geological model of Caferbeyli region. 


\section{Conclusions}

In this study, a low resistive layer is determined in the Caferbeyli region between 250 and $2000 \mathrm{~m}$ depth, and in the Çamurhamamı Spring region between 100 and $800 \mathrm{~m}$ depth, as shown in vertical sections. Horizontal sections also support these results. As the depth increases, the area of the low resistive layer increases respectively. The results are in conformity with stratigraphic logs. Both geological and geophysical data point out that the low resistivity zone lies between gneiss and marble formations. The unit has to have hot water circulation, which makes it a target for geothermal explorations. Explorations carried out near the flat plain part also showed that the low resistive layer is dipping towards the north. This may be taken as an indicator that the heater may be located on the northern side of the survey area. Therefore, a future study should be extended towards the north. Also a test drilling should be opened in Caferbeyli near the coordinate $4260500 \mathrm{~N}-594000 \mathrm{E}$ indicated in figure 9 (c) as a black star symbol.

\section{Acknowledgements}

This article is a part of Scientific project code 04.KB.FEN.006 and named 'Geothermal potential investigation of Salihli-Kurşunlu hot spring and its surroundings' sponsored by Dokuz Eylül University Scientific Research Fund. In this study, the CSAMT data acquisition part was done by the General Directorate of Mineral Research and Exploration of Turkey (MTA) in 1993. The authors are also deeply indebted to Prof. Mustafa Ergün for the constructive and thoughtful comments; to Prof. Harald Walderhaug for making English corrections in the text of the paper; to Prof. Ünsal Gemici for his kind opinions about general and structural geology of the field; to Assoc. Prof. Emin U Ulugergerli for providing WinGLink software; and the Salihli municipality for kindly providing the accommodation during the field works.

\section{References}

Akyol N, Zhu L, Mitchell B J, Sözbilir H and Kekovalı K 2006 Crustal structure and local seismicity in western Anatolia; Geophys. J. Int. 166 1259-1269.

Aldanmaz E 2002 Mantle source characteristics of alkali basalts and basanites in an extensional intracontinental plate setting, western Anatolia, Turkey: Implications for multi-stage melting; Int. Geol. Rev. 44(5) 440-457.

Baranov V 1957 A new method for interpretation of aeromagnetic maps pseudo-gravimetric anomalies; Geophysics 22 359-383.
Baranov V and Naudy H 1964 Numerical calculation of the formula of reduction to the magnetic pole; Geophysics $\mathbf{2 9}$ 67-79.

Blakely R J 1995 Potential Theory in Gravity 85 Magnetic Applications; London, Cambridge University Press.

Blakely R J and Simpson R W 1986 Approximating edge of source bodies from magnetic or gravity anomalies; Geophysics 51 1494-1498.

Bujakowski W, Barbacki A, Czerwinska B, Pajak L, Pussak M, Stefaniuk M and Trzesniowski Z 2010 Integrated seismic and magnetotelluric exploration of the Skierniewice, Poland, geothermal site; Geothermics 39 78-93.

Dolmaz M N, Hisarlı Z M, Ustaömer T and Orbay N 2005 Curie point depths based on spectrum analysis of the aeromagnetic data, West Anatolian Extensional Province, Turkey; Pure Appl. Geophys. 162(3) 571-590.

Gürer A, Gürer Ö F, Pinçe A and İlkışık O M 2001 Conductivity structure along the Gediz Graben, West Anatolia, Turkey: Tectonic Implications; Int. Geol. Rev. 43 11291144.

Koçyiğit A, Yusufoğlu H and Bozkurt E 1999 Evidence from the Gediz graben for episodic two-stage extension in western Turkey; J. Geol. Soc. London 156 605616.

Mackie R L, Madden T R and Wannamaker P E 1993 Three-dimensional magnetotelluric modeling using difference equations - Theory and comparisons to integral equation solutions; Geophysics 58(2) 215-226.

McKenzie D P 1978 Active tectonics of the AlpineHimalayan Belt: The Aegean Sea and surrounding regions; Geophys. J. Roy. Astron. Soc. 55 217-254.

Meju M A 2002 Geoelectromagnetic exploration for natural resources: Models, case studies and challenges; Surv. Geophys. 23 133-205.

Özelçi F 1973 Gravity anomalies of the eastern mediterranean; MTA J. 80 (in Turkish).

Paton S 1992 Active normal faulting, drainage patterns and sedimentation in southwestern Turkey; J. Geol. Soc. London 149 1031-1044.

Purvis M and Robertson A 2005 Sedimentation of the Neogene-recent Alasehir (Gediz) continental graben system used to test alternative tectonic models for western Turkey; Sedim. Geol. 173 373-408.

Ross H P and Moore J N 1985 Geophysical investigations of the Cove Fort-Sulphurdale geothermal system, Utah; Geophysics 50 1732-1745.

Sarı C 2003. Gravite Verileri ile Batı Anadolu'nun Kabuk Yapısı ve Grabenlerin Tortul Kalınlı̆̆ının Saptanması DEÜ-BAP Project Report No: 0908.97.08.02 (in Turkish).

Sarı C and Şalk M 2002 Analysis of gravity anomalies with hyperbolic density contrast: An application to the gravity data of Western Anatolia; J. Balkan Geophys. Soc. 5(3) 87-96.

Savin C, Ritz M, Join J-L and Bachelery P 2001 Hydrothermal system mapped by CSAMT on Karthala volcano, Grande Comore Island, Indian Ocean; J. Appl. Geophys. 48 143-152.

Seyitoğlu G and Scott B C 1996 The cause of N-S extensional tectonics in western Turkey: Tectonic escape vs. back-arc spreading vs. orogenic collapse; J. Geodyn. 22 $145-153$.

Sözbilir H 2002 Geometry and origin of folding in the Neogene sediments of the Gediz Graben, western Anatolia, Turkey; Geodinamica Acta 15 277-288.

Spichak V and Manzella A 2009 Electromagnetic sounding of geothermal zones; J. Appl. Geophys. 68 459478.

Sudha K, Tezkan B, Israil M and Rai J 2011 Combined electrical and electromagnetic imaging of hot fluids within 
fractured rock in rugged Himalayan terrain; J. Appl. Geophys. 74 205-214.

Suzuki K, Shinji T, Kenichiro K, Yasuhiro F, Tohru M and Akira J 2000 Case studies of electrical and electromagnetic methods applied to mapping active faults beneath the thick quaternary; Eng. Geol. 56 29-45.

Tarcan G, Filiz Ş and Gemici Ü 1998 Hydrogeological and geochemical study of the Salihli (Manisa) geothermal fields; Bull. Turkish Petrol. Geol. Assoc. 10 61-86.
Taymaz T, Jackson J and McKenzie D 1991 Active tectonics of the north and central Aegean Sea; Geophys. J. Int. 106 433-490.

Thanassoulas C, Tselentis G A and Kolios N 1986 Geothermal prospecting by geoelectric soundings in NE Greece; Geophys. Prospect. 34 83-97.

Yılmazer S 2003 Salihli Belediyesi adına Kurşunlu Kaplıcalarında yapılan sıcak su kuyusu lokasyon çalışması raporu; Unpublished report, İzmir (in Turkish).

MS received 27 February 2014; revised 15 July 2014; accepted 25 August 2014 